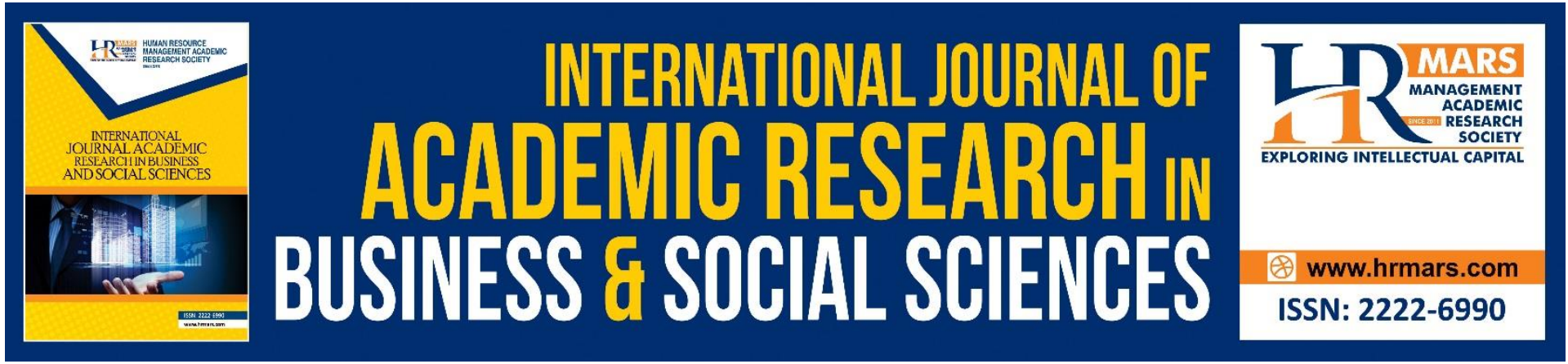

\title{
Capital Adequacy Challenges in Facing Economic Conflicts in Banking Institutions
}

Mohd Afzanizam Abdul Rashid, Shahsuzan Zakaria, Amiril Azizah, Abdul Rahim Ridzuan

To Link this Article: http://dx.doi.org/10.6007/IJARBSS/v11-i8/10183

DOI:10.6007/IJARBSS/v11-i8/10183

Received: 11 June 2021, Revised: 15 July 2021, Accepted: 02 August 2021

Published Online: 20 August 2021

In-Text Citation: (Rashid et al., 2021)

To Cite this Article: Rashid, M. A. A., Zakaria, S., Azizah, A., \& Ridzuan, A. R. (2021). Capital Adequacy Challenges in Facing Economic Conflicts in Banking Institutions. International Journal of Academic Research in Business and Social Sciences, 11(8), 678-686.

Copyright: (c) 2021 The Author(s)

Published by Human Resource Management Academic Research Society (www.hrmars.com)

This article is published under the Creative Commons Attribution (CC BY 4.0) license. Anyone may reproduce, distribute, translate and create derivative works of this article (for both commercial and non-commercial purposes), subject to full attribution to the original publication and authors. The full terms of this license may be seen at: http://creativecommons.org/licences/by/4.0/legalcode

Vol. 11, No. 8, 2021, Pg. 678 - 686

Full Terms \& Conditions of access and use can be found at http://hrmars.com/index.php/pages/detail/publication-ethics 


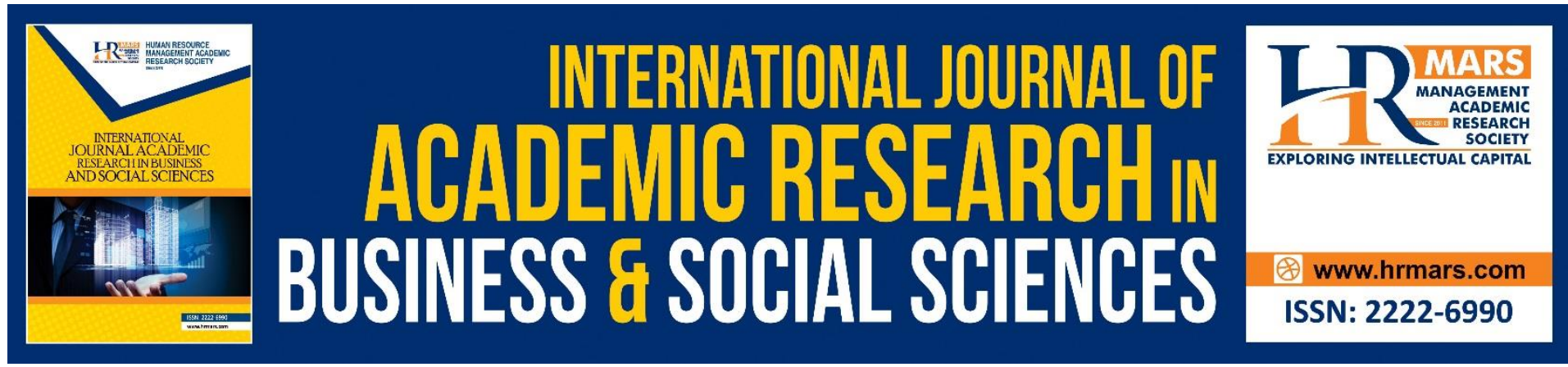

\title{
Capital Adequacy Challenges in Facing Economic Conflicts in Banking Institutions
}

\author{
Mohd Afzanizam Abdul Rashid \\ Chief Economist Bank Islam Malaysia Berhad Malaysia \\ Email: afzanizam@bankislam.com.my
}

\begin{abstract}
Shahsuzan Zakaria
Senior Lecturer Faculty of Management and Business Universiti Teknologi MARA, Malaysia

Email: shah81@uitm.edu.my
\end{abstract}

Amiril Azizah

Lecturer Politeknik Negeri Samarinda Indonesia

Email: amirilazizah@polnes.ac.id

\begin{abstract}
Abdul Rahim Ridzuan
Senior Lecturer Faculty of Management and Business Universiti Teknologi MARA, Malaysia

Email: Rahim670@uitm.edu.my
\end{abstract}

\begin{abstract}
The banking sector is one of the sectors that is affected by the economic instability. The function played by the institution in assisting the economic volatility of a country is through capital adequacy and liquidity requirements. Capital adequacy has a direct effect towards income generation. However, as a result of the volatile global and Malaysian economic conditions, particularly because of the outbreak of Covid-19 pandemic, Bank Negara Malaysia (BNM) has given leeway to the banking institutions for the Liquidity Coverage Ratio (LCR) to be below 100 percent. Meanwhile, in recent years, the banking sector's LCR was more than the targeted 100 percent. The question arises whether the decline in LCR parameters to below 100 percent is suitable to be implemented by all banking institutions? It is certain that with the reduction of LCR, liquidity risk caused by lack of funding at a reasonable cost to finance the operations of the bank and provide liabilities at the required time will definitely be faced by the bank. The ability to comply with the expected and unexpected cash flow requirements will be affected, thereby creating liquidity risk and increase in credit risk.
\end{abstract}

Keywords: Capital Adequacy, Economic Conflict, Banking Institution

\section{Introduction}

In the development of a country's economic sector, one of the important factors that encourages economic success and sustainability is by strengthening the financial sector. The 
financial sector, especially in the banking industry provides a significant contribution when able to create earnings consistently. Capital adequacy is the basis of stability and strength in the banking institution in facing shocks and indicating risky implications to the financial statement. Banks will be stable if they have a reasonable capital ratio as well as satisfactory levels of solvency and liquidity. The higher the capital ratio, the better the bank's ability in coping market uncertainties, and able to deal with various risks. If the value of the capital is high, banks can finance management cost and be the major contributor in generating earnings, while increasing the confidence of the depositors, investors, and stakeholders.

\section{Capital Adequacy Perspective}

Basically, capital adequacy can be defined as a level of capital that allows banks to absorb losses, and at the same time have sufficient funds to maintain and operate as a financial entity continuously. Bank's capital must sufficient to protect depositors and creditors from losses. Mohamad (2009) states that capital is the bank's capital ratio that includes capital base Tier 1 capital and Tier 2 capital. Shrieve and Dahl (1992) detailed capital as a portion of the liabilities in the balance sheet amount which includes paid-up capital, reserve funds, retained earnings, and other capital. Capital and reserve consist of own fund or core capital of a bank which is closely related with the readiness of an institution in facing market risk and will determine the success of the adopted risk management model. Therefore, as higher risk management is undertaken, higher capital is required. Thus, by law, this ratio has a positive relationship with financially sound bank, and negative relationship on the losses incurred (Daud, 2013). In addition, this is one of the most important variables in measuring the base of stability and resilience of a banking institution, including dual banking system, which is the Islamic banking as an alternative to the existing banking system, and the Islamic banking entirely. A capital adequacy ratio that compares the value of equity and total asset will indicate the ratio of the bank's ability to decline in earnings because of losses caused by risky financial activities or investments.

Bank Negara Malaysia (BNM) determines the minimum capital requirement in accordance with the standards issued by the Bank for International Settlement (BIS). According to Section 14 of BAFIA (1989), every licensed institution must maintain the minimum funds and capital as stipulated by BNM. Historically, in 1959, BNM had stipulated that local banks must hold minimum capital fund of RM2 million. Meanwhile, in 1990, this rate was increased to RM20 million as 'precaution', parallel with the increasingly encouraging development of the banking system. Foreign banks are also required to hold capital fund as 'precaution' to enable them to compete with local banks, whereby the banks were required to hold minimum capital fund of RM5 million in 1959, and this rate was increased to RM25 million in 1983. Prior to the introduction of capital ratio framework by BNM in 1989, banks were required to hold a minimum capital ratio of $4 \%$ for local banks and $6 \%$ for foreign banks. Financial liberalisation and a more open landscape give larger space to capital adequacy of banking institutions where financial liberalisation attracts foreign investors into developing countries. The inflow of foreign capital can stimulate capital formation in banking and domestic economic growth that can play a role as a source of domestic investment financing, and is aimed to increase economic competitiveness and development in the banking institution (Aznaim, 2017). 


\section{Factors and Implications of Capital Control}

BNM has presented several justifications proposing for capital control in banking activities. Among the justifications include the level of exposure of bank activities to risk, which will cause banks to hold 'precaution' funds to enable the bank to absorb the losses that will be incurred due to systematic or unsystematic risks. In addition, the risk of moral hazard of capital adequacy is also necessary to prevent the occurrence of this problem which indicates that capital adequacy is a form of deterrent to the management that is prone to undertake high risk in order to generate high returns. However, when the situation is otherwise or fails, it will affect other parties specifically, the depositors. The issue of restricting the capital growth of capital adequacy also impedes the capital growth which is rapid and unreasonable. For example, commercial banks and finance companies are unable to expand the total loan amount when the borrowing limit is maximised. In addition, there are several other factors that can affect capital adequacy including the quality of bank management. This factor will affect the favourable revenue and earnings to the banking institutions when a bank organization is led by high quality management team. Various dimensions and aspects of management are seen to ensure the banking institutions remain dynamic at the maximum level of efficiency.

The level of liquidity owned by the bank will affect the provision of liquidity taken over by the capital contributor whereby the effect will be observed by bank management, thus resulting to limited capital owned by the bank (Aznaim, 2017). The other factor is observed from the efficiency level of the banking institutions, which is influenced by the quality of banking systems and operations. A high efficiency level will allow the bank to earn profits which will strengthen the capital of the bank. Deposit structure is also important where banks obtain funds largely from deposits and other investments, and will incur high costs when these payments are unable to be paid by earned income, and such losses must be absorbed by the capital owned, thus causing lack of capital. Meanwhile, the level of quality and behaviour of stakeholders that are future-oriented is preferred because these stakeholders will strive to raise capital to the maximum level to contribute to bank's capital strength.

The minimum stipulation of capital and rules profit-sharing earned by BNM has set the minimum level of capital that a bank must hold to overcome any unforeseen risks, which will cause impact where banks will have stronger capital, thus forming good financial condition. However, if a bank experiences insufficient capital, conflicts may occur due to the manipulation of the internal risk model (unsystematic risk) by the bank's management to reduce the impact of determining capital adequacy rules. The increase in losses by individual banks indicates that banking institutions seldom internalize the cost of failure on investors, government agencies, and overall stability.

In the volatile Malaysian economy that is worsening with worldwide outbreak of the Covid-19 pandemic, financial analysts are optimistic that the Malaysian banking system has sufficient liquidity to ease financial stress and support intermediary activities. Due to the pressure of Covid-19 and economic recovery strategy, BNM has given flexibility in the Liquidity Coverage Ratio (LCR) to banking institutions to below $100 \%$. Meanwhile, in previous years, LCR achieved by banking institutions exceeded the target of $100 \%$. For example, in 2019 , LCR was achieved at $149 \%$ with all banks recording LCR levels exceeding the regulatory 
minimum level of $100 \%$ (Figure 1). Thus, these liquid assets are available to be used by banks during periods of financial stress and economic downturn.

Figure 1. Decrease in Liquidity Coverage Ratio

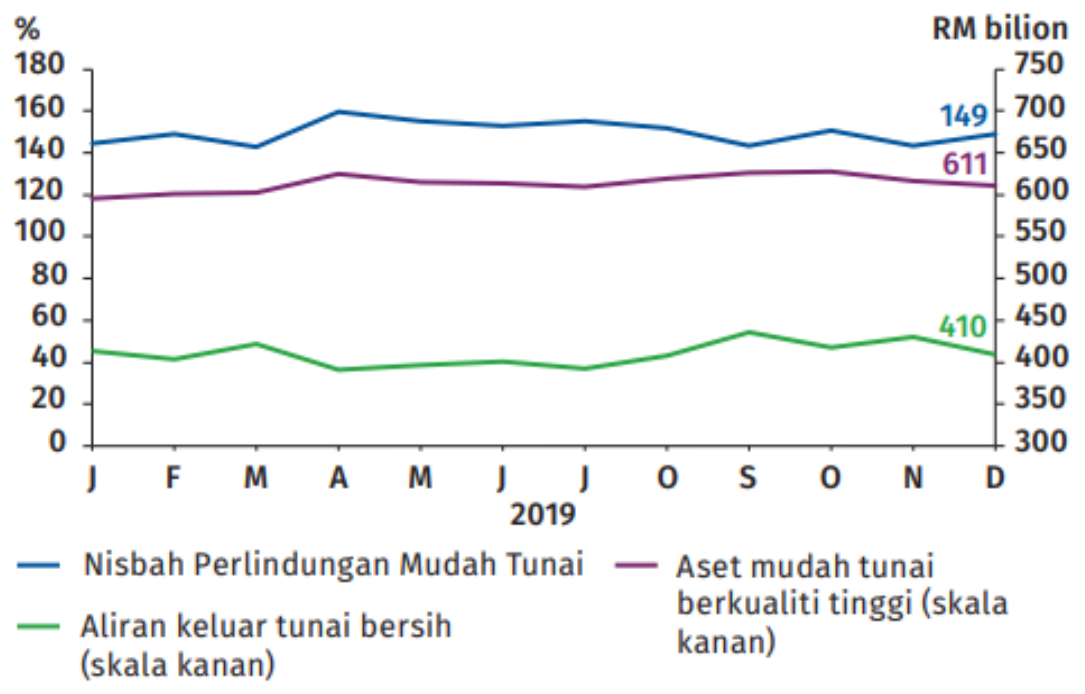

Source: Financial Stability Review, Second Half 2019, BNM

The question arises, (1) Does the decline in the parameter of LCR below $100 \%$ is appropriate to be implemented by all banking institutions? and (2) Does the flexibility provided is able to maintain stability of short-term financing and balance the financing offered by the banks to selected sectors? With the reduction of LCR, undoubtedly liquidity risk caused by lack of access to obtain funds at a reasonable cost to finance the bank's operation and provide liabilities at the required time will inevitably experience by the banks. The ability to meet the expected and unforeseen need of cash flow will be affected. In other words, liquidity risk will exist with the reduction of LCR. Certainly, as a local banking institution that competes with other dynamic foreign banks, there is a need to balance between responsibilities in meeting short-term financial demand and the return from long-term investment even when the reduction in LCR is given.

Similar scenario is seen when BNM lowered the targeted percentage for Capital Adequacy Ratio (CAR) which is presumed to reach minimum of more than $8 \%$ as a good indicator, $6.4 \%$ to $7.9 \%$ as a moderate indicator and less than or equal to $6.4 \%$ as a bad indicator under Basel II. Beginning March 25, 2020, the banking sector was allowed to reduce to $2.5 \%$, including Capital Conservation Buffer (CCB) which was reduced to $2.5 \%$, targeting to a minimum of $10.5 \%$ under Basel III. Due to the economic constraints caused by the Covid19 pandemic, this situation may cause the banks to deal with the issue of low capital adequacy, and financial institutions that are also exposed to the increased credit risk. The credit strength of most banks will be weakened due to the widespread and prolonged economic shocks. Several other implications were also accepted by the banking institutions as a result of contraction of CAR, including restricting the liquidity level. There is possibility that the provision of will be undertaken by the capitalists, thus causing the capital owned by the bank to be limited. The level of asset quality is also disrupted by low levels of capital adequacy when banks are unable to conduct their operations smoothly. 
In addition, the decline of the liquidity ratio eases compliance with the minimum capital adequacy ratio, and the granting of moratorium on the borrowers indicates that the response by the central bank to economic shocks is constantly evolving. Moreover, several financing facilities are also provided by BNM directly to Small and Medium Enterprises (SMEs) to solve cash flow problems. Basically, the Overnight Policy Rate (OPR) will be used when the country faces risk of serious economic slowdown or the possibility of recession. For example, the OPR has been lowered by 125 basis points from January 2020 to July 2020, where the interest rate is at an all-time low of $1.75 \%$. Furthermore, the Statutory Reserve Requirements (SRR) was also reduced to $2 \%$ and the institutions were allowed to use securities such as Malaysian Government Securities (MGS) and Government Investment Issue (GII) for the purpose of meeting the requirements of SRR.

Based on this action, it is noted that when a negative shock occurs, all forms of restrictions or barriers such as determining total liquidity as well as the total capital available must be relaxed. Thus, when these restrictions are lifted when confronted with the risk of a recession, is there a need to be revisited from the aspect of usability? Will this ad hoc approach be maintained? These are interesting questions as the banking institution is also a business entity responsible for generating consistent earnings for the shareholders. Most of these shareholders are institutional investors or Government Linked Investment Companies (GLIC) such as Permodalan Nasional Berhad (PNB), Employees Provident Fund (EPF), Incorporated Pension Trust Fund (KWAP), Lembaga Tabung Haji (LTH) and Lembaga Tabung Angkatan Tentera (LTAT). The financial performance for a banking institution also greatly influences the dividend rate announced among GLICs. This situation has a significant impact on the general public as the OPR is at the lowest level of all time, and has had a negative impact on the earnings of banking institutions including entities listed on Bursa Malaysia.

Table 1. OPR Decision until January 2021

\begin{tabular}{|c|c|c|}
\hline Duration & Change in OPR (\%) & New OPR Level (\%) \\
\hline 20 January2021 & 0 & 1.75 \\
\hline 3 November 2020 & 0 & 1.75 \\
\hline 10 September 2020 & 0 & 1.75 \\
\hline 7 July 2020 & -0.25 & 1.75 \\
\hline 5 May 2020 & -0.5 & 2.00 \\
\hline 3 March 2020 & -0.25 & 2.50 \\
\hline 22 January 2020 & -0.25 & 2.75 \\
\hline
\end{tabular}

Source: https://www.bnm.gov.my/opr-decision-and-statement/-/tag/opr-2020

Based on Table 1, the OPR was reduced by 50 basis points to $2 \%$, with the ceiling and floor rates for the OPR corridors reduced to $2.25 \%$ and $1.75 \%$, respectively. The implications to the decline of this rate explained that when the OPR is lowered, financing rates especially financing contracts with financing rates that changes according to the OPR are lowered immediately. Meanwhile, fixed deposits will continue to be maintained at the same level until the period of the deposit matures. This situation focuses on the profit level of the bank, which is measured as Net Interest Margin (NIM) for conventional banking institutions and Islamic banking institutions. The NIM is a key factor that will drive the level of profitability of a banking institution. If the bank has a portfolio of loans and financing where the variable rate is large, then the impact will be greater compared to a bank with a larger fixed rate portfolio or 
financing rate. Therefore, the monetary policy administered by BNM has a direct impact on NIM. In addition, constraints or restrictions on liquidity or capital adequacy results also cause direct impact on financial performance. For example, LCR compliance will lead to holding a certain number of assets known as High Liquid Assets (HQLA) such as MGS and GII, which eventually led the Asset Yield or Rate of Return on Assets to be low in meeting the requirements of $L C R$. This can therefore impact NIM, which is the most important factor in determining the earnings level of a bank, and dividends among GLICs. Therefore, this issue requires precise observation on the compliance with the parameters aimed at ensuring that financial soundness or the financial resilience level of a bank is not compromised, and the bank has the freedom on undertaking risks for the purpose of gaining earnings that will eventually be received by the community through dividend payments by GLIC.

Table 2. Equity holdings by PNB Group, EPF, LTH, KWAP and LTAT in banks listed on Bursa Malaysia

\begin{tabular}{|c|c|}
\hline Duration & Holding Percentage* \\
\hline 15 December 2019 & 36.2 \\
\hline 16 December 2019 & 35.8 \\
\hline 17 December 2019 & 36.0 \\
\hline 18 December 2019 & 34.2 \\
\hline 19 December 2019 & 37.1 \\
\hline 20 March 2020 & 39.9 \\
\hline 20 June 2020 & 40.5 \\
\hline 20 September 2020 & 40.3 \\
\hline
\end{tabular}

Note: *Estimated Figures

Source Bloomberg LP (2020)

Table 3. ASB, EPF and LTH dividends against the Bursa Malaysia Equity Return Financial Index

\begin{tabular}{|c|c|c|c|c|}
\hline Year & $\begin{array}{c}\text { Return on } \\
\text { Equity } \\
\text { percentage of } \\
\text { the Bursa } \\
\text { Malaysia } \\
\text { Financial } \\
\text { Services Index }\end{array}$ & $\begin{array}{c}\text { ASB Dividend } \\
\text { Percentage }\end{array}$ & $\begin{array}{c}\text { KWSP Dividend } \\
\text { Percentage }\end{array}$ & $\begin{array}{c}\text { Lembaga } \\
\text { Tabung Haji } \\
\text { (LTH) Hibah } \\
\text { Percentage }\end{array}$ \\
\hline 2014 & 13.10 & 8.5 & 6.75 & 8.25 \\
\hline 2015 & 10.63 & 7.75 & 6.40 & 8.00 \\
\hline 2016 & 9.77 & 7.25 & 5.70 & 5.75 \\
\hline 2017 & 10.26 & 8.25 & 6.90 & 6.25 \\
\hline 2018 & 10.71 & 7.00 & 6.15 & 1.25 \\
\hline 2019 & 9.92 & 5.50 & 5.45 & 3.05 \\
\hline
\end{tabular}

Note: The percentage figures include bonus

Source: Bloomberg LP, Entities' Announcements 
Identifying a mid-point is viewed as an ideal effort that involves the interest of the public, in terms of stability of the financial system whereby the banking institution is the core of an economy. The bank as a business entity, which is closely regulated by BNM will continue to generate sustainable earnings. Extreme approaches such as remodelling the capital adequacy and liquidity framework may not be feasible as the standards set by the BIS are the main reference point in the matter of financial stability of banking institutions. Concurrently, intense competition in the industry especially in the context of Industrial Revolution 4.0 or IR 4.0 has forced banks to take higher risks where the SME sector is seen as the industry of choice to expand its portfolio with higher returns. Undoubtedly, the existence of guarantee institutions such as Business Financing Guarantee Companies (SJPP) and Credit Guarantee Corporation (CGC) have assisted banks to expand their businesses in the SME sector effectively where risk is likely to be guaranteed by these entities.

However, such solution is still within the framework whereby banks must adhere to the capital adequacy ratio as well as liquidity which can hinder the strategies undertaken by banks for taking higher risks. This predicament is believed to impact the SMEs as well as microenterprises that rely heavily on capital for expanding their businesses. Yet, the health crisis stemming from Covid-19 outbreak seems to be breaking the tradition of the banks and the central bank, which require close cooperation between borrowers and financial institutions to endure difficult times collectively. At present, the relationship between customers and banks should be two-way so that a win-win solution is achieved. Borrowers must pay their debts. However, as they are greatly affected by Covid-19, the deferment of installation payments is timely in order to improve their financial position. The banks are not favourable on unpaid loan, as it will result to incurring losses on the capital issued. Thus, the current Covid-19 circumstances has inferred that a better solution must be deduced from the context of devising a system that monitors the strength of the financial level of a bank. Certainly, this must also be revisited form the accounting point of view so that the system created does not penalize the banks when taking business risks.

\section{Conclusion}

This chapter discussed the scenario of capital adequacy in banking institutions in Malaysia. Capital adequacy ratio is a measure of a bank's strength which is based on the predetermined minimum capital ratio. In a volatile economic situation, coupled with regulatory control and international standards, local banks constantly strive to strengthen capital adequacy to ensure efficiency, sustainability, and success as a business entity. Thus, the strategy of strengthening capital adequacy will yield strategic liquidity management in supporting the ability of banking institutions to generate profits and safeguard the interests of stakeholders; and minimizing the negative implications of risk control on the level of capital adequacy.

\section{Acknowledgement}

This research is financed by RMI, UiTM Melaka. 


\section{References}

Aznaim, A. L. N. (2017). Implikasi dasar liberalisasi perkhidmatan kewangan terhadap perbankan Islam di Malaysia/Noor Aznaim Abd Latib (Doctoral dissertation, University of Malaya).

Bank Negara Malaysia. (2020). Monetary Policy Statement. Kuala Lumpur: Bank Negara Malaysia.

Bank Negara Malaysia. (2019). Tinjauan Kestabilan Kewangan Separuh Kedua 2019. Kuala Lumpur: Bank Negara Malaysia.

Bloomberg, L. P. (2020). Company filings.

Bloomberg L. P. (2020). Entities' Announcement

Daud, N. A. (2013). Prestasi Perbankan Di Malaysia: Analisis Camel. Prosiding Perkem VIII, 1, 1331-39.

Mohamad, M. T. (2009). Penentu keuntungan sistem perbankan Islam di Malaysia: kajian di bank-bank Islam terpilih (Doctoral dissertation, Jabatan Syariah dan Ekonomi, Akademi Pengajian Islam, Universiti Malaya).

Shrieves, R. E., \& Dahl, D. (1992). The relationship between risk and capital in commercial banks. Journal of Banking \& Finance, 16(2), 439-457. 